\title{
Impurities of crude glycerol and their effect on metabolite production
}

\author{
Dorota Samul • Katarzyna Leja • Wlodzimierz Grajek
}

Received: 28 August 2013 / Accepted: 4 November 2013 / Published online: 13 December 2013

(C) The Author(s) 2013. This article is published with open access at Springerlink.com

\begin{abstract}
Glycerol is a valuable raw material for the production of industrially useful metabolites. Among many promising applications for the use of glycerol is its bioconversion to high value-added compounds, such as 1,3-propanediol (1,3PD), succinate, ethanol, propionate, and hydrogen, through microbial fermentation. Another method of waste material utilization is the application of crude glycerol in blends with other wastes (e.g., tomato waste hydrolysate). However, crude glycerol, a by-product of biodiesel production, has many impurities which can limit the yield of metabolites. In this mini-review we summarize the effects of crude glycerol impurities on various microbial fermentations and give an overview of the metabolites that can be synthesized by a number of prokaryotic and eukaryotic microorganisms when cultivated on glycerol.
\end{abstract}

Keywords 1,3-Propanediol · Crude glycerol · Impurities · Pure glycerol

\section{Introduction}

Glycerol is a valuable raw material for the production of industrially useful metabolites. As such, it has found many applications in the cosmetic, paint, automotive, food, tobacco, pharmaceutical, pulp and paper, leather and textile industries. It is also used as a feedstock for the production of various chemicals (Wang et al. 2001; da Silva et al. 2009). One of many promising applications for the use of glycerol is its bioconversion to high value-added compounds through

D. Samul $(\varangle) \cdot$ K. Leja $\cdot$ W. Grajek

Department of Biotechnology and Food Microbiology, Poznań

University of Life Sciences, Wojska Polskiego 48, 60-627 Poznań,

Poland

e-mail: dorota.orczyk@up.poznan.pl microbial fermentation. Glycerol is not only cheap and abundant, but its greater degree of reduction than sugars offers the opportunity to obtain reduced chemicals, such as succinate, ethanol, xylitol, propionate, hydrogen, among others, at higher yields than those obtained by using sugars (Dharmadi et al. 2006; da Silva et al. 2009; Leja et al. 2011a). Glycerol is also used in 1,3-propanediol (1,3-PD) synthesis. 1,3-PD is an industrially valuable chemical intermediate with potential applications in the production of polymers (among others, polyesters, polyethers, polyurethanes) (Homann et al. 1990; Zeng and Biebl 2002), cosmetics (Huang et al. 2002), foods, lubricants (Barbirato et al. 1998), medicines (Adachi et al. 1995), and as an intermediate for the synthesis of heterocyclic compounds, such as indoles and quinolones (Tsuji et al. 1987; Zeng et al. 1993; Menzel et al. 1997; Katrlík et al. 2007; Kubiak et al. 2012; Myszka et al. 2012).

Crude glycerol is synthesized as a by-product of biodiesel production. In recent years, biodiesel production has significantly increased in a number of European countries, and according to the U.S. Energy Information Administration issued on July 30, the European Union (EU) produced 111 million gallons in May 2013. This increase in biodiesel production has resulted in a concomitant increase in the amount of crude glycerol produced (Dharmadi et al. 2006; Deckwer 1995). As a consequences some EU biodiesel companies are experiencing severe problems in how to get rid themselves of the excess glycerol as its disposal is quite expensive. The collapse of glycerol prices has also caused a major problem to these companies (Willke and Vorlop 2004; Dharmadi et al. 2006). Thus, solutions to the management of this raw material are badly needed. One possible approach is to use crude glycerol in the production of industrially useful metabolites in fermentation processes. Glycerol is abundant in the natural environment since it is a structural component of many lipids. It is also one of the principal compatible solutes, being widely produced in response to decreased extracellular water activity 
during osmoregulation in yeasts (Wang et al. 2001; da Silva et al. 2009). Due to its occurrence in nature, many known microorganisms can naturally utilize glycerol as a sole carbon and energy source, including Klebsiella pneumoniae (Biebl et al. 1998), K. oxytoca (Homann et al. 1990), K. aerogenes (Biebl et al. 1998), Lactobacillus reuterii, L. buchnerii, L. collinoides (da Silva et al. 2009), Enterobacter agglomerans (Barbirato et al. 1998), E. aerogenes (da Silva et al. 2009), Clostridium butyricum (Colin et al. 2001), C. pasteurianum (Biebl et al. 1992; Dabrock et al. 1992), C. diolis, C. perfringens (Youngleson et al. 1989; Hao et al. 2008), Citrobacter freundii (Boenigk et al. 1993; Daniel et al. 1995; Malinowski 1999), Pelobacter carbinolicus, Rautella planticola, and Bacillus welchii (Saxena et al. 2009; Leja et al. 2011b). Thus, glycerol is a promising and abundant new carbon source for applications in those industrial microbiology where it can substitute for traditional carbohydrates, such as sucrose, glucose and starch, such as in some industrial fermentation processes. However, the use of crude glycerol, without purification, in fermentation is a difficult process. Impurities in this material influence biochemical pathways in bacteria cells and can limit the efficiency of metabolite production. Although utilization of crude glycerol in the fermentation medium without prior purification offers a remarkable advantage against the traditional use of pure glycerol as substrate, there have been only a few published reports describing its use as a sole carbon source (e.g., Adachi et al. 1995; Barbirato et al. 1998; Colin et al. 2001; Dharmadi et al. 2006; Hao et al. 2008; Desbois and Smith 2010; Papanikolaou et al. 2008).

In the study reported here we identified the main impurities present in crude glycerol obtained as a by-product during biodiesel production and compared the yield of metabolites obtained from pure and crude glycerol. Based on these results, we present here a number of possible some solutions on how to limit the negative influence of impurities in crude glycerol.

\section{Microorganisms able to product industrially useful metabolites from crude glycerol}

One of the most promising methods for the valorization of crude glycerol is its use in biotransformation processes for the biosynthesis of high value-added metabolic products. A large group of microorganisms is capable of assimilating glycerol as a carbon source in the synthesis of many useful products, such as 1,3-PD, ethanol, hydrogen, polyhydroxyalkanoates, and organic acids (Amaral et al. 2009; da Silva et al. 2009; André et al. 2010; Chatzifragkou et al. 2011a, b, c). A number of microorganisms can grow on glycerol, including Actinobacillus succinogenes, Aspergillus niger, Blakeslea trispora, Burkholderia sp., Chlorella protothecoides, Citrobacter freundii, Clostridium buturicum, Clostridium pasteurianum, Cunninghamella echinulata, Cupriavidus necator, Enterobacter aerogenes, Escherichia coli, Gluconobacter sp., Klebsiella pneumoniae, Kluyvera cryocrescens, Lentinula edodes, Mortierella ramanniana, Mucor sp., Pseudomonas oleovorans, Rhodotorula glutinis, Schizochytrium limacinum, Staphylococcus caseolyticus, Yarrowia lipolytica, and Zobellella denitrificans (Petitdemange et al. 1995; González-Pajuelo et al. 2004; Hirschmann et al. 2005; Ito et al. 2005; Mu et al. 2006; Rymowicz et al. 2006, 2009; Fakas et al. 2008; Mantzouridou et al. 2008; Volpato et al. 2008; Cavalheiro et al. 2009; Habe et al. 2009; Rywińska et al. 2009; André et al. 2010; Andreeßen et al. 2010; Chatzifragkou et al. 2010; Chee et al. 2010; Ibrahim and Steinbüchel 2010; Liang et al. 2010; Ashby et al. 2011; Choi et al. 2011; O'Grady and Morgan 2011; Saenge et al. 2011; Vlysidis et al. 2011; Bellou et al. 2012; Metsoviti et al. 2012; Venkataramanan et al. 2012; Wilkens et al. 2012). Table 1 presents a number of the microorganisms that are able to convert crude glycerol to commercially useful metabolites as well as transform the main impurities of this raw material..

The transesterification process is carried out during biodiesel (upper phase, nonpolar ester) and crude glycerol (lower phase, polar glycerol) formation. Crude glycerol consists of glycerol, alcohol (typically methanol), inorganic salts (as residues from catalysts), free fatty acid, unreacted mono-, di-and triacylglycerols, methyl esters, and water (Pagliaro and Rossi 2010). The composition of crude glycerol depends mainly on the kind of raw glycerol used for the production of biodiesel, the conditions of the transesterification process, and the conditions of the separate non-polar phase from the polar phase (Hájek and Skopal 2010). The purification of biodiesel is very important, as the quality of the obtained by-product (purity of glycerol) depends on it. The by-products of biodiesel production can contain from 40 to $99 \%$ glycerol depending on the method of purification (Van Gerpen 2005; Leung et al. 2010; Singhabhandhu and Tezuka 2010). The main impurities in crude glycerol are free fatty acid, inorganic salts, and alcohol (Chatzifragkou and Papanikolaou 2012; Venkataramanan et al. 2012). The presence of these impurities in crude glycerol has a very negative effect on the morphology and biochemical processes of bacterial cells and, consequently, lower concentrations of metabolites are obtained than crude glycerol than from pure glycerol (Ito et al. 2005; Wilkens et al. 2012). However, a few examples of the use of crude glycerol with a neutral or positive influence on the synthesis of certain metabolites can be found in the literature (Chatzifragkou et al., 2011a; b; Jun et al. 2010).

Impurities in glycerol interact with each other and can have a synergic effect. Alcohol influences a cell membrane and increases its permeability, but its effect strictly depends on the length of the carbon chain and its concentration. For example, methanol, an aliphatic alcohol with one carbon atom, does not influence the cell membrane (in low concentrations) and does not decrease metabolite production 
Table 1 Microorganisms able to convert crude glycerol to commercially useful metabolites and the main impurities in crude glycerol having an impact on the conversion of this raw material

\begin{tabular}{|c|c|c|c|}
\hline Strain & Metabolic product & Glycerol impurities & Reference \\
\hline Clostridium butyricum VPI 1718 & 1,3-Propanediol (1,3-PD) & Oleic acid & Chatzifragkou et al. 2011a b \\
\hline Clostridium butyricum DSM 15410 & $1,3-\mathrm{PD}$ & Methanol & Moon et al. 2010 \\
\hline Klebsiella pneumoniae DSM 2026 & $1,3-\mathrm{PD}$ & No data & Mu et al. 2006 \\
\hline Clostridium pasteurianum ATCC 6013 & $1,3-\mathrm{PD}$ & Oleic, linoleic acid & Venkataramanan et al. 2012 \\
\hline Enterobacter aerogenes HU-101 & Hydrogen & Salts & Ito et al. 2005 \\
\hline Yarrowia lipolytica Wratislavia AWG7 & Citric acid & Methanol, salts & Rywińska et al. 2009 \\
\hline Yarrowia lipolytica N15 & Citric acid & Fatty acids & Kamzolova et al. 2011 \\
\hline Basfia succiniciproducens DD1 & Succinic acid & No data & Scholten et al. 2009 \\
\hline Gluconobacter sp. NBRC103465 & Glyceric acid & Methanol & Habe et al. 2009 \\
\hline Yarrowia lipolytica Wratislavia K1 & Erythritol & No data & Rymowicz et al. 2009 \\
\hline Paracoccus denitrificans & Polyhydroxyalkanoates & Salts & Mothes et al. 2007 \\
\hline Cupriavidus necator DSM 545 & Polyhydroxyalkanoates & Sodium salts & Cavalheiro et al. 2009 \\
\hline Staphylococcus caseolyticus EX17 & Lipase & No data & Volpato et al. 2008 \\
\hline Cryptococcus curvatus & Lipid & Methanol & Liang et al. 2010 \\
\hline Aspergillus niger NRRL 364 & Lipid, oxalic acid & $\begin{array}{l}\text { Potassium and sodium salts, } \\
\text { non-glycerol organic } \\
\text { material, methanol }\end{array}$ & André et al. 2010 \\
\hline Lentinula edodes AMRL 121 & Lipid & $\begin{array}{l}\text { Potassium and sodium salts, } \\
\text { non-glycerol organic } \\
\text { material, methanol }\end{array}$ & André et al. 2010 \\
\hline Cunninghamella echinulata ATHUM 4411 & Lipid & No data & Fakas et al. 2008 \\
\hline Mortierella ramanniana & Lipid & No data & Bellou et al. 2012 \\
\hline Blakeslea trispora & $\beta$-Carotene & Soap, methanol & Mantzouridou et al. 2008 \\
\hline
\end{tabular}

(Venkataramanan et al. 2012). Anther group of glycerol impurities are salts. High concentrations of monovalent salts decrease van der Waals force in a lipid membrane and cause swelling of the cell membrane. This swelling exerts has a negative effect on the energetic barrier in a lipid layer of the membrane and changes the course of biochemical processes in the cells; for example, it influences the transportation of nutrition factors through the cell membrane (Petrache et al. 2006). The free fatty acids (linoleic, stearic, oleic acids) have a major influence on the synthesis of metabolites. Fatty acids are components of the cell membrane and are incorporated into the acyl chains and alk-1-enyl chains of cellular lipids; their presence thus disturbs the correct process of metabolite synthesis (Venkataramanan et al. 2012). Stearic acid is a saturated fatty acid with an 18-carbon chain which is present in the fermentation medium; it aligns with the fatty acid tails of the membrane. Oleic acid consists only of one double bond and it causes a kink in the molecule which hampers the diffusion of nutrient factors and metabolites through the membrane (Furusawa and Koyama 2004). Linoleic acid is a compound with a high degree of unsaturation which has two kinks which cause the inhibition of nutrient factors and thereby limit the synthesis of some products (Desbois and Smith 2010). The unsaturated fatty acids with two or more double bonds which are present in crude glycerol have strong influence on the diffusion of the substrate along the membrane (Venkataramanan et al. 2012).

Crude glycerol is recognized as a renewable waste substrate with numerous applications, and its bioconversion into high value-added metabolic products would provide a valuable option for the efficient management of biodiesel production waste and development of sustainable technologies. The possibility of using crude glycerol as a substrate for the production of important industrial products depends on the degree of its purity. The biotechnological production of 1,3PD as a valuable by-product of biodiesel production, namely, the production of crude glycerol, is a promising and encouraging alternative to traditional chemical synthesis.

\section{Comparison of pure and crude glycerol}

Although the utilization of raw glycerol in fermentation medium without prior purification is economically much more advantageous than the traditional use of pure glycerol as substrate, only a few reports have appeared in the literature on the use of this substrate as a sole carbon source (Barbirato et al. 1998; González-Pajuelo et al. 2004; Hirschmann et al. 2005; Mu et al. 2006; Rymowicz et al. 2006; Papanikolaou 
et al. 2008). The biosynthesis of high value-added metabolic products is one of the more promising uses of crude glycerol for biotechnological conversion (Zeng and Sabra 2011; Posada et al. 2012). The final product concentrations and yield of different metabolites from pure and crude glycerol are compared in Table 2.

In general, there is a larger yield of metabolite product associated with the use of pure glycerol. However, some researchers have reported that the efficiency of the 1,3-PD production process is the same for both types of glycerol (Chatzifragkou et al. 2011b) or even that the efficiency of the production process is higher using crude glycerol (Rywińska et al. 2009; Jun et al. 2010; Jitrwung and Yargeau 2011). One reason for this inconsistency is that the quantity and quality of the composition of the crude glycerol was not analyzed in many studies. In some cases the glycerol was rich in vitamins and other nutrition factors used by bacteria, resulting in higher metabolic activity (Hilaly and Binder 2002). In the study of Jun et al. (2010), the crude glycerol consisted of methanol $(0.27 \mathrm{wt} \%)$, water $(0.05 \mathrm{wt} \%)$, nonglycerol organic matter (17.0 wt\%), sodium $(13.6 \mathrm{mg} / \mathrm{kg})$, potassium $(70 \mathrm{mg} / \mathrm{kg})$, and magnesium $(1.9 \mathrm{mg} / \mathrm{kg})$. However, these impurities did not decrease the yield of metabolite production - to the contrary, it was higher than when the pure raw material was used. Because many authors do not provide information on the level of impurities in crude glycerol, the quality of glycerol used in the various studies cannot be compared. We can assume that the crude glycerol used in the study of Jun et al. (2010) was good quality glycerol. Additionally, pure glycerol is often purified up to only $80 \%$; thus, the difference between the raw and pure materials used in some earlier studies was insignificant.

In order to overcome the obstacle of impurities encountered in the composition of the biodiesel-derived crude glycerol utilized, a number of researchers have proposed various pretreatment strategies. In particular, the treatment of diluted crude glycerol with hydrochloric acid precipitates the residual fatty acids, which can be further removed by centrifugation (Moon et al. 2010; Venkataramanan et al. 2012). Moreover, the application of organic solvents (hexane, heptane, octane, petroleum ether, and $n$-hexanol) has been also reported as a means of biodiesel-derived crude glycerol pretreatment for the removal of residual fatty acids (Rehman et al. 2008; Anand and Saxena 2012). Additionally, Anand and Saxena (2012) found that the cultivation of Citrobacter freundii on the above-mentioned pretreated glycerol wastes gives results similar to those obtained with pure glycerol in terms of microbial growth and 1,3-PD production, indicating once again the strong negative impact of residual free fatty acids on bacterial growth.

Glycerol as a low-cost by-product of the biodiesel industry can be considered to be a renewable building block for biorefineries. The biosynthesis of high value-added metabolic products from crude glycerol is a current and important issue in the valuation of raw material and use of crude glycerol in many branches of the industry. The development of technology that would allow for the efficient use of by-products of biodiesel production is also an important issue. Effective utilization of crude glycerol is crucial to the commercialization and further development of biodiesel production. The effective utilization of crude glycerol will contribute to the viability of biodiesel.

Table 2 Final product concentrations and yield of different metabolites from pure and crude glycerol

\begin{tabular}{|c|c|c|c|c|c|c|}
\hline Strain & Metabolic product & $\begin{array}{l}\text { Final product } \\
\text { concentrations } \\
\text { from pure glycerol } \\
(\mathrm{g} / \mathrm{L})\end{array}$ & Yield (g/g) & $\begin{array}{l}\text { Final product } \\
\text { concentrations } \\
\text { from crude glycerol } \\
(\mathrm{g} / \mathrm{L})\end{array}$ & Yield $(\mathrm{g} / \mathrm{g})$ & Reference \\
\hline Clostridium butyricum AKR102a & 1,3PD & 93.7 & 0.52 & 76.2 & 0.51 & Wilkens et al. 2012 \\
\hline Citrobacter freundii FMCC-B 294 & 1,3-PD & 68.1 & 0.40 & 66.3 & 0.38 & Metsoviti et al. 2013 \\
\hline Clostridium butyricum VPI 1718 & 1,3-PD & 11.3 & 0.57 & 11.3 & 0.57 & Chatzifragkou et al. 2011b \\
\hline Klebsiella pneumoniae DSM 4799 & 1,3-PD & 13.8 & 0.35 & 17.1 & 0.42 & Jun et al. 2010 \\
\hline Clostridium butyricum 2.1. & 1,3-PD & 31.9 & 0.46 & 28.0 & 0.40 & $\begin{array}{l}\text { Orczyk and Szymanowska- } \\
\text { Powałowska } 2012\end{array}$ \\
\hline Klebsiella pneumoniae DSM 2026 & 1,3-PD & 61.9 & 0.41 & 53 & 0.39 & Mu et al. 2006 \\
\hline Yarrowia lipolytica Wratislavia AWG7 & Citric acid & 19.0 & 0.69 & 18.1 & 0.66 & Rywińska et al. 2009 \\
\hline Yarrowia lipolytica Wratislavia K1 & Citric acid & 20.4 & 0.45 & 22.1 & 0.43 & Rywińska et al. 2009 \\
\hline Yarrowia lipolytica N15 & Citric acid & 98.0 & 0.70 & 71 & 0.90 & Kamzolova et al. 2011 \\
\hline Aspergillus niger LFMB 1 & Oxalic acid & No data & No data & 21.5 & 0.61 & André et al. 2010 \\
\hline Gluconobacter sp. NBRC103465 & Glyceric acid & 54.7 & 0.33 & 45.9 & 0.26 & Habe et al. 2009 \\
\hline Aspergillus niger NRRL 364 & Lipid & No data & No data & 3.4 & 0.21 & André et al. 2010 \\
\hline Gluconobacter sp. NBRC103465 & Dihydroxy-acetone & 33.7 & 0.20 & 28.2 & 0.16 & Habe et al. 2009 \\
\hline Staphylococcus caseolyticus EX17 & Lipase & $145.8 \mathrm{U} / \mathrm{L}$ & No data & $127.3 \mathrm{U} / \mathrm{L}$ & No data & Volpato et al. 2008 \\
\hline Cupriavidus necator DSM 545 & $\begin{array}{l}\text { Polyhydroxy-alkanoates } \\
\text { P(3HB) }\end{array}$ & 51.2 & 0.36 & 38.1 & 0.34 & Cavalheiro et al. 2009 \\
\hline
\end{tabular}




\section{Utilization of crude glycerol in blends with other wastes}

Industrial fermentations need raw materials that both fulfill the requirements of the organism and are available in a high quantity and quality. Most fermentation media consist of carbon sources, nitrogen sources, minerals and specific nutrients. The carbon to nitrogen ration $(\mathrm{C} / \mathrm{N})$ in the growth medium is considered to be the most decisive factor.

There are few published reports on the utilization of crude glycerol in blends with other wastes. Suitable nitrogen sources include, for example, sources of nitrate or ammonium ions, urea, yeast extract, beef extract, proteose peptone, soybean meal, hydrolysates of casein, distiller's solubles, and the like. Distiller's solubles can be corn steep liquor, bottom stillage from ethanol distillation, or soybean solubles (Hilaly and Binder 2002).

Tomato waste, comprising tomato skin and seeds, is of particular interest because it is produced in huge amounts in all Mediterranean countries and is a causing severe environmental problems. This pollution could be avoided if there were alternative ways for the valorization of tomato waste. These wastes could then be used as fermentation feedstock to produce microbial lipids (Fakas et al. 2008). Fakas et al. (2008) researched the effect of organic nitrogen on the uptake rate of both glucose and glycerol and observed distinct patterns of lipid accumulation by Cunninghamella echinulata. Nevertheless, when glycerol was used as a carbon source instead of glucose, the uptake rate as well as the biomass production and the lipid accumulation processes were unaffected by the removal of organic nitrogen from the tomato waste hydrolysate (TWH). The lipid content in biomass produced on original TWH supplemented with glycerol was lower than that achieved on original TWH supplemented with glucose. Growth of $C$. echinulata was inhibited in TWH media containing glycerol as a carbon source at concentrations of $>60 \mathrm{~g} / \mathrm{L}$. The glycerol inhibition problem, however, could be resolved by applying fed-batch cultivation systems in which glycerol could be added gradually to the culture. The favorable glycerol conversion yields obtained in this study indicate that glycerol could be an efficient substrate.

The nature of the carbon, a nitrogen source used as raw material for fermentations, depends first on the particular fermentation process and subsequently on the requirements and productivity of the microorganisms. Waste media should be individually evaluated for their capability to support growth microorganisms and metabolite production. Research on simultaneous technology in which wastes from the first step of the process could be used as raw materials in other processes is promising and should be further developed. Supplementation of pure materials by crude raw materials has a tremendous ecological and economic potential for biotechnology processes. This would be of particular interest if TWH and raw glycerol could be used as co-substrates, partly because of the very low (or even negative) economic value of the substrates and partly because this approach could offer the means to recycle, at least partially, the raw glycerol produced during biodiesel manufacturing. Thus, optimization of such processes is necessary. The main problem is that crude materials have unstandardized composition and are of diverse quality depending on the source. Waste media should therefore be individually evaluated for their capability to support growth and metabolite production. Isolation and selection of microorganisms which are able to effectively utilize wastes is a main issue in introducing such processes into industrial applications.

\section{Conclusion}

The production of industrially useful metabolites from crude glycerol is an important issue, as it may be (partially) responsible for the price of biodiesel. A large group of microorganisms are known to produce 1,3-PD, organic acids, and other metabolites. The efficiency of metabolite synthesis depends mainly on the type of glycerol and the microorganisms used. In this report, we have made an attempt to analyze impurities present in crude glycerol, a by-product of biodiesel production, and examine its effect on the efficiency of metabolite production. The solution to this problem is still needed because these impurities limit the up-scaling of fermentation processes and hence it remains impossible to obtain pure products. These purification techniques are very expensive, and alternative methods must therefore be developed. In the Department of Biotechnology and Food Microbiology, Poznan University of Life Sciences, investigations on the production of 1,3-PD from crude glycerol by new isolated Clostridium butyricum strain (Orczyk and SzymanowskaPowałowska 2012; Orczyk et al. 2012) are currently being carried out. We are also researching the influence of impurities in crude glycerol on the efficiency of metabolite production. Some data on the utilization of crude glycerol in blends with other waste materials are available. In our opinion, this is a promising technology and should be further tested in our research project in the near future.

Acknowledgments The work was prepared within the framework of the project PO IG 01.01.02-00-074/09, co-funded by the European Union from the European Regional Development Fund within the framework of the Innovative Economy Operational Programme 2007-2013.

Open Access This article is distributed under the terms of the Creative Commons Attribution License which permits any use, distribution, and reproduction in any medium, provided the original author(s) and the source are credited. 


\section{References}

Adachi K, Kohara T, Nakao N, Arita M, Chiba K, Mishina T et al (1995) Design, synthesis, and structure-activity relationships of 2-substituted2-amino-1,3-propanediols: discovery of a novel immunosuppressant, FTY720. Bioorg Med Chem Lett 5(8):853-856

Amaral PF, Ferreira TF, Fontes GC, Coelho MAZ (2009) Glycerol valorization: new biotechnological routes. Food Bioprod Proc 87: 179-186

Anand P, Saxena RK (2012) A comparative study of solvent-assisted pretreatment of biodiesel derived crude glycerol on growth and 1,3propanediol production from Citrobacter freundii. New Biotechnol 29(2):199-205

André A, Diamantopoulou P, Philippoussis A, Sarris D, Komaitis M, Papanikolaou S (2010) Biotechnological conversions of biodiesel derived water glycerol into added-value compounds by higher fungi: production of biomass, single cell oil and oxalic acid. Ind Crop Prod 31:407-416

Andreeßen B, Lange AB, Robenek H, Steinbüchel A (2010) Conversion of glycerol to poly(3-hydroxypropionate) in recombinant Escherichia coli. Appl Environ Microbiol 76:622-626

Ashby RD, Solaiman DKY, Strahan GD (2011) Efficient utilization of crude glycerol as fermentation substrate in the synthesis of poly (3-hydroxybutyrate) biopolymers. J Am Oil Chem Soc 88:949-959

Barbirato F, Himmi EH, Conte T, Bories A (1998) 1,3-Propanediol production by fermentation: an interesting way to valorize glycerin from the ester and ethanol industry. Ind Crop Prod 7:281-9

Bellou S, Moustogianni A, Makri A, Aggelis G (2012) Lipids containing polyunsaturated fatty acids synthesized by Zygomycetes grown on glycerol. Appl Biochem Biotechnol 166:146-158

Biebl H, Marten S, Hippe H, Deckwer WD (1992) Glycerol conversion to 1,3-propanediol by newly isolated clostridia. Appl Microbiol Biotechnol 36:592-597

Biebl H, Zeng AP, Menzel K, Deckwer WD (1998) Fermentation of glycerol to 1,3-propanediol and 2,3-butanediol by Klebsiella pneumoniae. Appl Microbiol Biotechnol 50:24-29

Boenigk R, Bowien S, Gottschalk G (1993) Fermentation of glycerol to 13-propanediol in continuous cultures of Citrobacter freundii. Appl Microbiol Biotechnol 38:453-457

Cavalheiro JMBT, de Almeida MCMD, Grandfils C, da Fonseca MMR (2009) Poly(3-hydrobutyrate) production by Cupriavidus necator using waste glycerol. Process Biochem 44:509-515

Chatzifragkou A, Papanikolaou S (2012) Effect of impurities in biodiesel-derived waste glycerol on the performance and feasibility of biotechnological processes. Appl Microbiol Biotechnol 95:13-27

Chatzifragkou A, Dietz D, Komaitis M, Zeng AP, Papanikolaou S (2010) Effect of biodiesel-derived waste glycerol impurities on biomass and 1,3-propanediol production of Clostridium butyricum VPI 1718. Biotechnol Bioeng 107:76-84

Chatzifragkou A, Makri A, Belka A, Bellou S, Mavrou M, Mastoridou M, Mystrioti P, Onjaro G, Aggelis G, Papanikolaou S (2011a) Biotechnological conversions of biodiesel derived waste glycerol by yeast and fungal species. Energy 36:1097-1108

Chatzifragkou A, Papanikolaou S, Dietz D, Doulgeraki AI, Nychas GJE, Zeng AP (2011b) Production of 1,3-propanediol by Clostridium butyricum growing on biodiesel-derived crude glycerol through a non-sterilized fermentation process. Appl Microbiol Biotechnol 91: 101-112

Chatzifragkou A, Aggelis G, Komaits M, Zeng AP, Papanikolaou S (2011c) Impact of anaerobiosis strategy and bioreactor geometry on the biochemical response of Clostridium butyricum VPI 1718 during 1,3-propanediol fermentation. Bioresource Technol 102: $10625-10632$
Chee JY, Tan Y, Samian MR, Sudesh K (2010) Isolation and characterization of a Burkholderia sp. USM (JCM15050) capable of producing polyhydroxyalkanoate (PHA)from triglycerides, fatty acids and glycerols. J Polym Environ 18:584-592

Choi WJ, Hartono MR, Chan WH, Yeo SS (2011) Ethanol production from biodiesel-derived crude glycerol by newly isolated Kluyvera cryocrescens. Appl Microbiol Biotechnol 89:1255-1264

Colin T, Bories A, Lavigne C, Moulin G (2001) Effects of acetate and butyrate during glycerol fermentation by Clostridium butyricum. Curr Microbiol 43:238-243

da Silva GP, Mack M, Contiero J (2009) Glycerol: a promising and abundant carbon source for industrial microbiology. Biotechnol Adv 27:30-39

Dabrock B, Bahl H, Gottschalk G (1992) Parameters affecting solvent production by Clostridium pasteurianum. Appl Environ Microbiol 58:1233-1239

Daniel R, Stuertz K, Gottschalk G (1995) Biochemical and molecular characterization of the oxidative branch of glycerol utilization by Citrobacter freundii. J Bacteriol 177:4392-4401

Deckwer WD (1995) Microbial conversion of glycerol to 1,3propanediol. FEMS Microbiol Rev 16:143-149

Desbois AP, Smith VJ (2010) Antibacterial free fatty acids: activities, mechanisms of action and biotechnological potential. Appl Microbiol Biotechnol 85:1629-1642

Dharmadi Y, Murarka A, Gonzalez R (2006) Anaerobic fermentation of glycerol by Escherichia coli: a new platform for metabolic engineering. Biotechnol Bioeng 94:821-829

Fakas S, Papanikolaou S, Galiotou-Panayotou M, Komaitis M, Aggelis G (2008) Organic nitrogen of tomato waste hydrolysate enhances glucose uptake and lipid accumulation in Cunninghamella echinulata. J Appl Microbiol 105:1062-1070

Furusawa H, Koyama N (2004) Effect of fatty acids on the membrane potential of an alkaliphilic bacillus. Curr Microbiol 48:196-198

González-Pajuelo M, Andrade JC, Vasconcelos I (2004) Production of 1, 3-propanediol by Clostridium butyricum VPI 3266 using a synthetic medium and raw glycerol. J Ind Microbiol Biot 31:442-446

Habe H, Shimada Y, Fukuoka T, Kitamoto D, Itagaki M, Watanabe K, Yanagishita H, Sakaki K (2009) Production of glyceric acid by Gluconobacter sp. NBRC3259 using raw glycerol. Biosci Biotechnol Biochem 73:1799-1805

Hájek M, Skopal F (2010) Treatment of glycerol formed by biodiesel production. Bioresour Technol 101:3232-3245

Hao J, Wei W, Jiesheng T, Jilun L, Dehua L (2008) Decrease of 3 hydroxypriopionaldehyde accumulation in 1,3-propanediol production by over-expressing dhaT gene in Klebsiella pneumoniae TUAC01I. Ind Microbiol Biotechnol 35:735-741

Hilaly AK, Binder TP (2002). Method of recovering 1,3-propanediol from fermentation broth. Patent No.: US 6,479,716 B2. U.S. Patent and Trademarks Office, Alexandria

Hirschmann S, Baganz K, Koschik I, Vorlop KD (2005) Development of an integrated bioconversion process for the production of 1,3propanediol from raw glycerol waters. Landbauforsch Volk 55: 261-267

Homann T, Tag C, Biebl H, Deckwer WD, Schink B (1990) Fermentation of glycerol to 1,3-propanediol by Klebsiella and Citrobacter strains. Appl Microbiol Biotech 33:121-126

Huang H, Gong CS, Tsao GT (2002) Production of 1,3-propanediol by Klebsiella pneumoniae. Appl Biochem Biotechnol 98-100:687-98

Ibrahim MHA, Steinbüchel A (2010) Zobellella denitrificans strain MW1, a newly isolated bacterium suitable for poly(3hydroxybutyrate) production from glycerol. J Appl Microbiol 108: 214-225

Ito T, Nakashimada Y, Senba K, Matsui T, Nishio N (2005) Hydrogen and ethanol production from glycerol-containing wastes discharged after biodiesel manufacturing process. J Biosci Bioeng 100:260-265 
Jitrwung R, Yargeau V (2011) Optimization of media composition for the production of biohydrogen from waste glycerol. Int J Hydrogen Energy 36:9602-9611

Jun SA, Moon C, Kang CH, Kong SW, Sang BI, Um Y (2010) Microbial fed-batch production of 1,3-propanediol using raw glycerol with suspended and immobilized Klebsiella pneumoniae. Appl Biochem Biotechnol 161:491-501

Kamzolova SV, Fatykhova AR, Dedyukhina EG, Anastassiadis SG, Golovchenko NP, Morgunov IG (2011) Citric acid production by yeast grown on glycerol-containing waste from biodiesel industry. Food Technol Biotechnol 49:65-74

Katrlík J, Vostiar I, Sefcovicová J, Tkác J, Mastihuba V, Valach M et al (2007) A novel microbial biosensor based on cells of Gluconobacter oxydans for the selective determination of 1,3-propanediol in the presence of glycerol and its application to bioprocess monitoring. Anal Bioanal Chem 388:287-295

Kubiak P, Leja K, Myszka K, Celińska E, Spychała M, SzymanowskaPowałowska D, Czaczyk K, Grajek W (2012) Physiological predisposition of various Clostridium species to synthetize1,3propanediol from glycerol. Process Biochem 47:1308-1319

Leja K, Czaczyk K, Myszka K (2011a) 1,3-Propanediol synthesis by biotechnological way using Clostridium spp. Afr J Biotechnol 10(54):11093-11101

Leja K, Myszka K, Czaczyk K (2011b) The use of microorganisms in 1,3propanediol production. Afr J Microbiol Res 5(26):4652-4658

Leung DYC, Wu X, Leung MKH (2010) A review on biodiesel production using catalyzed transesterification. Appl Energy 87:1083-1095

Liang YN, Sarkany N, Cui Y, Blackburn JW (2010) Batch stage study of lipid production from crude glycerol derived from yellow grease or animal fats through microalgal fermentation. Bioresour Technol 101:6745-6750

Malinowski J (1999) Evaluation of liquid extraction potentials for downstream separation of 1,3-propanediol. Biot Tech 13:127-130

Mantzouridou F, Naziri E, Tsimidou MZ (2008) Industrial glycerol as a supplementary carbon source in the production of $\beta$-carotene by Blakeslea trispora. J Agric Food Chem 56:2668-2675

Menzel K, Zeng AP, Deckwer WD (1997) High concentration and productivity of 1,3-propanediol from continuous fermentation of glycerol by Klebsiella pneumoniae. Enzyme Microb Technol 20: $82-86$

Metsoviti M, Paramithiotis S, Drosinos EH, Galiotou-Panayotou M, Nychas GJE, Zeng AP, Papanikolaou S (2012) Screening of bacterial strains capable of converting biodiesel-derived raw glycerol into 1,3-propanediol, 2,3-butanediol and ethanol. Eng Life Sci 12:57-68

Metsoviti M, Zeng AP, Koutinas AA, Papanikolaou S (2013) Enhanced 1,3-propanediol production by a newly isolated Citrobacter freundii strain cultivated on biodiesel-derived waste glycerol through sterile and non-sterile bioprocesses. J Biotechnol 163:408-418

Moon C, Ahn JH, Kim SW, Sang BI, Um Y (2010) Effect of biodiesel derived raw glycerol on 1,3-propanediol production by different microorganisms. Appl Biochem Biotechnol 161:502-510

Mothes G, Schnorpfeil C, Ackermann JU (2007) Production of PHB from crude glycerol. Eng Life Sci 7:475-479

Mu Y, Teng H, Zhang DJ, Wang W, Xiu ZL (2006) Microbial production of 1,3-propanediol by Klebsiella pneumoniae using crude glycerol biodiesel preparations. Biotechnol Lett 28:1755-1759

Myszka K, Leja K, Olejnik-Schmidt AK, Czaczyk K (2012) Isolation process of industrially useful Clostridium bifermentans from natural samples. J Biosci Bioeng 113:631-3

O'Grady J, Morgan JA (2011) Heterotrophic growth and lipid production of Chlorella protothecoide on glycerol. Bioprocess Biosyst Eng 34: $121-125$

Orczyk D, Szymanowska-Powałowska D (2012) Isolation of bacteria of the genus Clostridium able to conversion of glycerol to 1,3- propanediol and optimization of medium. Engine Sci Technol 2(5):44-59 (in Polish)

Orczyk D, Szymanowska-Powałowska D, Leja K (2012) Microbiological conversion of pure and crude glycerol to 1,3-propanediol. Acta Sci Pol Biotechnol 11(3):15-22

Pagliaro M, Rossi M (2010) Glycerol: properties and production. In: Pagliaro M, Rossi M (eds) The future of glycerol, 2nd edn. The Royal Society of Chemistry, London, pp 1-28

Papanikolaou S, Fakas S, Fick M, Chevalot I, Galiotou-Panayotou M, Komaitis M, Marc I, Aggelis G (2008) Biotechnological valorisation of raw glycerol discharged after bio-diesel (fatty acid methyl esters) manufacturing process: Production of 1,3propanediol, citric acid and single cell oil. Biomass Bioenerg 32: 60-71

Petitdemange E, Dürr C, Abbad AS, Raval G (1995) Fermentation of raw glycerol to 1,3-propanediol by new strains of Clostridium butyricum. J Ind Microbiol 15:498-502

Petrache HI, Tristram-Nagle S, Harries D, Kucerka N, Nagle JF, Parsegian VA (2006) Swelling of phospholipids by monovalent salt. J Lipid Res 47:302-309

Posada JA, Rincón LE, Cardona CA (2012) Design and analysis of biorefineries based on raw glycerol, addressing the glycerol problem. Biores Technol 111:282-293

Rehman A, Matsimura M, Nomura N, Sato S (2008) Growth and 1,3propanediol production on pre-treated sunflower oil bio-diesel raw glycerol using a strict anaerobe-Clostridium butyricum. Curr Res Bacteriol 1:7-16

Rymowicz W, Rywińska A, Żarowska B, Juszczyk P (2006) Citric acid production from raw glycerol by acetate mutants of Yarrowia lipolytica. Chem Pap 60:391-394

Rymowicz W, Rywińska A, Marcinkiewicz M (2009) High-yield production of erythritol from raw glycerol in fed-batch cultures of Yarrowia lipolytica. Biotechnol Lett 31:377-380

Rywińska A, Rymowicz W, Żlarowska B (2009) Biosynthesis of citric acid from glycerol by acetate mutants of Yarrowia lipolytica in fed-batch fermentation. Food Technol Biotechnol 47:1-6

Saenge C, Cheirsilp B, Suksaroge TT, Bourtoom T (2011) Potential use of oleaginous red yeast Rhodotorula glutinis for the bioconversion of crude glycerol from biodiesel plant to lipids and carotenoids. Process Biochem 46:210-218

Saxena RK, Anand P, Saran S, Isar J (2009) Microbial production of 1,3propanediol: recent developments and emerging opportunities. Biotechnol Adv 27:895-913

Scholten E, Renz T, Thomas J (2009) Continuous cultivation approach for fermentative succinic acid production from crude glycerol by Basfia succiniciproducens DD1. Biotechnol Let 31:1947-1951

Singhabhandhu A, Tezuka T (2010) A perspective on incorporation of glycerin purification process in biodiesel plants using waste cooking oil as feedstock. Energy 35:2493-2504

Tsuji Y, Huh KT, Watanabe Y (1987) Ruthenium-complex-catalyzed Nheterocyclization. Syntheses of quinolines and indole derivatives from aminoarenes and 1,3-propanediol of glyxols. J Org Chem 52: $1673-80$

Van Gerpen J (2005) Biodiesel processing and production. Fuel Process Technol 86:1097-1107

Venkataramanan KP, Boatman JJ, Kurniawan Y, Taconi KA, Bothum GD, Scholz C (2012) Impact of impurities in biodiesel-derived crude glycerol on the fermentation by Clostridium pasteurianum ATCC 6013. Appl Microbiol Biotechnol 93:1325-1335

Vlysidis A, Binns M, Webb C, Theodoropoulos C (2011) Glycerol utilisation for the production of chemicals: Conversion to succinic acid, a combined experimental and computational study. Biochem Eng J 58-59:1-11 
Volpato G, Rodrigues RC, Heck JX, Ayub MAZ (2008) Production of organic solvent tolerant lipase by Staphylococcus caseolyticus EX17 using raw glycerol as substrate. J Chem Technol Biotechnol $83: 821-828$

Wang ZX, Zhuge J, Fang H, Prior BA (2001) Glycerol production by microbial fermentation: a review. Biotechnol Adv 19:201-223

Wilkens E, Ringel AK, Hortig D, Willke T, Vorlop KD (2012) High level production of 1,3-propanediol form crude glycerol by Clostridium butyricum AKR102a. Appl Microbiol Biotechnol 93:1057-1063

Willke TH, Vorlop KD (2004) Industrial bioconversion of renewable resources as an alternative to conventional chemistry. Appl Microbiol Biotechnol 66:131-142
Youngleson JS, Jones WA, Jones DT, Woods DR (1989) Molecular analysis and nucleotide sequence of the adh1 gene encoding an NADPH-dependent butanol dehydrogenase gene in the Gram-positive anaerobe Clostridium acetobutylicum. Gene 78:355-364

Zeng AP, Biebl H (2002) Bulk chemicals from biotechnology: the case of 1,3-propanediol production and the new trends. Tools Appl Biochem Eng 74:239-59

Zeng AP, Sabra W (2011) Microbial production of diols as platform chemicals, Recent progresses. Curr Opin Biotech 22(6):749-757

Zeng AP, Biebl H, Schlieker H, Deckwer WD (1993) Pathway analysis of glycerol fermentation by Klebsiella pneumoniae: regulation of reducing equivalent balance and product fermentation. Enzyme Microb Technol 15:770-779 